\section{ANCIENT GREEK AND LATIN: A COMPARISON}

\section{PETER WÜLFING \\ Professor of Latin, \\ Cologne University}

When the problems of our two subjects are under consideration, we generally speak of "ancient languages" or "classical philology" without paying much attention to the differences between the two disciplines thus linked together.

It is accordingly reasonable to seek further facts and arguments in a study of their differences.' The considerations I am going to set out spring from common-place beginnings, but lead at least partially to useful educational reflexions, even concerning credentials.

This method would find favour with the structuralists, since it is they who have given a new lease of life to that old instrument of thought, antithetical deliberation. The points of difference are numerous, and can easily be multiplied. Here I shall give a selection divided into two sections. In the first I shall define nine points of difference between the Greek and Roman worlds. In the second I shall very briefly examine these nine points from the educational angle. To conclude, I shall deal with a tenth matter.

First, two small preliminary remarks.

1) In Classics teaching, we are handing two subjects that are very different in terms of age. In Western Europe, Latin is a very longstanding school subject, but Greek is much more recent. It has only been taught for a couple of hundred years at the secondary level.

2) We only teach Greek after Latin. Until our own day there has been but little teaching of Greek independent of Latin.

This is important when we try to defend both subjects: it is, at least in Germany, much harder to defend Greek than Latin. The drop in numbers taking Greek in my country is alarming.
Having stated historical differences in the teaching of the two classical subjects, I proceed to their content.

\section{Part 1}

1. First, the Languages themselves. Greek is rich in morphemes and, much more than Latin, in particles. So Greek to a greater extent expresses the semantic content of discourse on surface, whilst Latin keeps it in deep structure. I give just a few features:

The definite article, absent from Latin.

The ten participles of the Greek verb, showing various relationship of time, aspect and voice; Latin has three.

The middle voice, which expresses so many shades of meaning.

The optative mood in addition to the subjunctive.

The capacity to modify any word by means of particles, whence

The liberation of word-order in the sentence. (The contrast with modern English is extreme, the latter language lacking syntactical signposts and so needing a rather fixed word-order in the sentence; French and German in this regard occupy different intermediary positions.)

Passing over many other details, Greek can have recourse to a rich synchronistic ability to create compound words, which in Latin is restricted, thanks mainly to the classicism of Cicero and Caesar. In contrast to the above, Latin keeps much of its semantic content at the implicit level; one may think of the participial phrase, the ablative absolute, or the conjunction cum, their wide variety of possible meanings.

In order to demonstrate the repercussions of these differences on teaching, I shall offer an example of what I mean, even though I reserve my discussion of the educational principles until Part 2. When pupils translate from Greek and Latin, they are not at all learning the same thing in each case: in translating from Greek, they are learning to suppress certain linguistic elements, i.e. to convert a number of them back into the deep structure of their own language. But in translating from Latin, they 
learn to make additions, and to render explicit what in Latin is implicit. Both of these experiences are extremely valuable, but they are different.

I should like to take my discussion of the two languages further: the difference alluded to also affects the study of style. We feel how greatly the Greeks loved the spoken word, which led them to invent not only rhetoric but also dialectic, logic, grammar, and the whole body of literary genres, viz all the artes sermocinales. The Romans, on the contrary, were always cautious, reticent, and economical with words. Their style was marked rather by density of expression, conciseness, the heritage of the lapidary style, the ritual formula, the language of the law-code and of the solemn occasion. Even when they used it in much the same way as the Greeks, whether in rhethoric or poetry, they wanted it to serve certain quite specific aims: a political platform, a practical requirement, the preservation of power preferably, and above all its legitimation.

2. Among the Greeks, love of theory speculation and abstraction have always been acknowledged, their ability to see through the particular to the general has been much admired; and their curiosity, the "history" of the Ionians, is recognised as their supreme charcteristic.

The Romans, on the other hand, rejected theory, or at least gave it a more limited role. Their rationalism always remains under the thumb of mos maiorum (an unthinkable restriction for the Greeks). Greek philosophy only interested the Romans in its political and ethical aspects. Then again, it is with the Romans that we feel a personal involvement in philosophy. Think of Lucretius, of the whole of his De Rerum Natura, and of the encomium of philosophy which Cicero pronounces in the Tusculanae, Book V. Would not a Greek philosopher have hidden such feelings?

3. These two ancient peoples offer us choice exemples of the antithesis between regionalism and centralism. The Greeks only found a national unity which was fragil and late, for it was their "tribes" and localities which each brought its own individual cultural heritage, gods, beliefs, rites, customs, musical traditions, dialects and poetry. They united only very slowly, under the growing influence of epic which had a Mycenaean basis and was strong enough to cross the frontiers of the individual "tribes". The Greeks were able to draw upon the riches of each of their constituent "tribes", leading and borrowing all that was best among them, Ionians receiving Aeolic lyric, Dorians Ionic epic, Athenians Doric choruses and Ionic prose, etc. and vice versa. What we call literary genres were originally means of poetic expression proper to the individual "tribes". Only later did they combine to create that unity which is Greek literature ${ }^{2}$.

Nothing of the kind occurred among the Romans. Firstly, there was no problem of dialects. Then, they inherited a bulk legacy of all the Greek literary genres at once. It was on this heritage that they worked, translating, imitating, sometimes excelling. This was done in the one city, Rome, which proved a centre of great attraction.

To this is added a complementary problem which interests us classicists greatly. We see Greek literature come into being from oral beginnings and we still sometimes underestimate the oral character of this "literature", even in the so-called classical period of the fifth and fourth centuries. The Romans adopted it just at the moment when it had finally become a written literature for good. They got to know it in its written form and they worked on it in writing.

So we are teaching two subjects worlds apart when we are explaining the Iliad and discussing the Aeneid: the former a poem transmitting the collective memory of a distant heroic age, orally composed and received, with a foundation difficult to analyse consisting of parts of varied origin, some already formulated elsewhere in other contexts. These parts have been brought together to give the poem a unity undeniable even if not clearly distinguishable. The latter, the Aeneid, is the work of a known author of historical date, who is putting a mythical past at the service of contemporary 
politics; from end to end it is subject to a precise purpose, the proof that Roman history is meant to culminate in Augustus.

The contrast between the oral and the written ought to be one of the main themes in the teaching of ancient literature, for it is there that we meet with the first change of media (we are now living through the third). Greek and Roman literature furnish us with both constrasting and complementary examples of this change.

4. Greek myth in all its richness is in our possession because it was put into written form while still in full flower. Its function was clear: to put the narration of significant situations and events at the disposal of those seeking their historical, moral and religious identity.

It is mistaken, moreover, to see in mythology a pre-rational means of thinking; on the contrary, it allows of considerable power of abstraction: it is myth which tells of the general, deriving it from the particular.

What about the Romans? With them, the palace of myth is taken by the res gestae, the collections of exploits of the Roman people providing examples for the present and the future. Whilst myths are no longer repeated in real life (they are all the more so in the imagination), the great deeds found in Roman history can and must be accomplished anew. Whether this be possible does not admit of doubt: the res gestae, true or otherwise, never depart from the framework of reality.

5. The Greek gods exist in flesh and blood, we are tempted to say, so recognisable are they with their human faces and figures. Yet their actions are merely secondary.

The appearance of the Roman gods is unimportant. They are identified with their power to act, their will, numen, which must be discovered and once known followed in the minutest detail. The Greek gods remain outside history; the Romans gods are part of it. They direct Roman history according to a plan of their own conception as is clearly shown in the Aeneid: Jupiter, Juno, Venus and later Mars and Quirinus intervene in Rome's development at precise moments.

6. The competitive spirit among the Greeks is well known - the spirit of the agon. Glaukos in the Iliad expresses it once for all (Il. 6, 208): "My father charged me always to be the best and to excel all others"

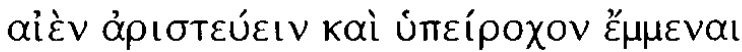
$\ddot{\alpha} \lambda \lambda \omega v$.

It is a spirit which could be described as typically European, but which, unless I am wrong, is nowhere more marked than among the Greeks, even today. Obviously it's a phenomenon found among us all. The English have given it the name of "one-up-manship". It is characteristic of the English spirit to aim to neutralise an attitude which is socially dubious by giving it the form of a society game.

The Romans never regarded individual performance as acceptable. They harshly punished the soldier who went to the attack before the command was given. The exemple of Fabius Maximus Rullianus is famous. He was condemned to death after winning a victory over the Samnites without the order of the current imperator (Livy 8, 30; cf. the legend of the Manliana imperia in 8,7)3.

Against the Greek ideal of individual self-sufficiency, of spontaneous action and taking one's own risks (of which Achilles and Ajax are typical incarnations), the Romans would have set their nobles, men who were held in check by the hierarchy of the gentes and by the authority of the Senate and magistrates; their deeds had to be done within the framework of the cursus honorum.

7. An almost necessary consequence is that for the Greeks it was the youthful male who most nearly corresponed to the ideal. Man at the peak of his strength and beauty, even with his hybris, even in his brillant failure, personifies the acme of heroic existence. What was true for the heroic age still flickered in a thoroughly bourgeois period, that of the New Comedy, e.g. of Menander. There, the young man, although his character is sometimes quite insignificant, nearly always gets the better of his father's generation. 
For the Romans, the mature man in his aetas firma et constans, full of dignitas, gravitas and auctoritas, would never be tempted to cross the frontiers of his society; in his case, the realities of power and of hierarchy, as established in the mos maiorum, would be respected.

8. Mos maiorum is the key phrase to enable us to see their respective attitudes to tradition. As my first exemple I should like to cite the freedom which the Greek poets enjoyed, in particular the tragedians, in their treatment of the myths which had come down to them. (The popular travesty of the myths was only a particular form of this - which had moreover its parallel in Roman satura.) Another exemple might be still more suggestive: the institution of the mediator during an internal crisis (Aristotle, in Pol. 3, 14, talks of the Aisymnetes) sometimes summoned from abroad, and that of lawmaker (nomothetes) appointed for the founding of colonies. Both recived extraordinary full powers to make new laws, institutions and rules which were rightly applauded for their originality, as they had never existed before, and for this end they made use of individual rational intelligence.

The Romans, however, could not follow this procedure. When, in exceptional circumstances, they thought it best to appoint a dictator, it was for well defined objectives (the technical term being rei gerundae causa "for the management of the political situation", with the implication "until the crisis has been resolved") and for a limited period of time, six months at most. And when they had to dispense with the libera res publica and Augustus took supreme power, what steps did he not take to prove he was doing nothing new, but quite the contrary was simply reviving the early republic's ancient institutions? It was because a little while before Julius Caesar had not taken the same precautions that he had failed.

For actions designed to change the government and the political system the Romans had a special expression, novis rebus studere. In the political context, they always regarded novum as having a pejorative slant ${ }^{4}$.
Nowadays we might well translate the expression as "being a terrorist".

As I have said, for the Romans rational innovation could only be rightfully undertaken within the framework of the mores maiorum. The contrast with the Greek institution of the "lawgiver" may be observed in the Corpus Iuris, the greatest achievement of the Roman mind. There, it is the very antiquity of the laws and institutions which gives them their authority - not a god of justice (as in Hesiod) nor the idea of the "highest good" (as in Plato) nor the comparative study of the constitutional theory of the Greek city-states (as in Aristotle) nor that of their lawcodes (undertaken by Theophrastus $)^{5}$, but the simple adapting of something very ancient to the circumstances of the day.

9. To conclude the first part of this discussion, I should like to examine the attitudes of the two peoples to political domination. For the Greek city-states and kingdoms it was obviously a temptation and a fascinating enterprise to rule vast areas of the world. The great power was certainly a topic discussed among the Greeks. They realised the risks and problems and debated the hybris of power but considered it neither possible nor desirable to maintain an empire or hegemony over a long period of time. Thus the Delian League and Alexander's empire both engaged the Greek mind and imagination, but scarcely survived a generation or two. Only the citystates, and kingdoms, such as Macedonia and Ptolemaic Egypt, with well defined frontiers, experienced real continuity.

In contrast the Romans found a practical, serious and continuous task in the enlargement and maintenance of their empire (and how can we know if they enlarged it in order to maintain it or if they kept it because they had already enlarged it?). With their pragmatic arrangements, with the efficient solutions they discovered by perseverance and even obstinacy, the Romans created lasting institutions in the whole realm of military, political and judicial organisation, government not only at home but even as far as the most 
distant provinces, the provisioning of large conurbations, the civil service, and the centralised administration ${ }^{6}$. Thus the Romans kept up the everlasting, unwinnable struggle between the ideal of lawful power and the harsh necessities of its daily exercise. They were well prepared for it by their character made up of the patrician gravitas and dignitas and an austere peasant realism. This combination was softened by the invincible spirit of satire, which enabled them to reduce the excesses of severitas (indeed, they could say "satura tota nostra est" simply because the Greeks did not cultivate dignitas and gravitas in that way).

While the Greeks tended to give up the task, too big and too heavy with contradictions, of ruling vast political conglomerations, the Romans had the capacity to persist and accept a less than ideal pragmatic solution, even, when the occasion demanded, a makeshift. They found this much more acceptable than a loss of power or security (we are nowadays used to this selfish concept of "security"). Unconquered nations were superbi, whom the Romans must debellare, and couldn't parcere except subiectis (cf. Aeneid 6, 85I ff).

\section{Part 2}

These points of difference, significant in themselves, will only gain their real interest if we can show their meaning for today and for our own teaching. These two last mentioned matters are, fortunately for us, more often identical than different. Moreover, even in Part 1 I have not always been able to refrain from alluding to them. So now I shall embark upon a quick survey to serve as a pedagogic summary, taking the points in reverse order, and starting with the last.

On9. We are quite familiar with the phenomenon of political domination and hegemony. We speak of superpowers, blocs, and zones of influence. We can study two approaches with regard to this phenomenon as we contrast the Greeks with the Romans. More precisely, while reading Thucydides it is also useful to bring in Roman imperialism. In the same way the complaints of King Mithridates in Sallust's Histories, and those of barbarian chiefs like Critognatus in Caesar, B. G. 7, 77 and Calgacus in Tacitus, Agricola $30 \mathrm{ff}$, would be thrown into higher relief if they were set against the Athenians' treatment of the Mytilenians (in Thuc. 3, 25-51) and of the Melians (Thuc. 5, $84 \mathrm{ff}$ ).

On 8. Reform or continuity, this is the great dilemma which is endlessly being inflicted on us, in so many sectors of our life; it finds important points of reference in our study of the means applied by each of the ancient peoples both to preserve tradition and to attain freedom from it.

On 7. Individual freedom, spontaneity and creativity are amongst the values we hold most dear. Yet we see them threatened by powerful movements, by direct state intervention and control, by industries which will more and more make use of electronic information devices, by indirect control otherwise called conformism, nourished by the media, by the consumer society, and mass tourism. All these things bring about a loss of individuality but at the same time spur us to distance ourselves. The question is, which ideal to fight for?

The attitudes of the two ancient peoples furnish us with two complementary models. It is our task to find a position somewhere between the youthful Greek hero-figure and the mature Roman patrician such as Cato and Scipio.

The idealisation of the young is familiar to us, moreover. The person who "aristeuei" is today the young, dynamic person, bursting with health, always at the peak of fitness.

On 6. All professional teachers are particulary alive to the repercurtions of the competitive spirit. How far should it be allowed to go? How far should it be encouraged? At what point should we preferably encourage cooperation? Hesiod already formed the distinction between good and bad eris 
"contention, rivalry", the latter being the kind of stirf which destroys all sense of community (Hesiod, Works and Days $11 \mathrm{ff}$., where he corrects his own Theogony $225 \mathrm{ff}$.). For ourselves the problem is yet more complex, for even good eris can cause havoc.

On 5. As regards deities, I confine myself to the mention of the problem of Nature: is it an object on which to exercise our will, or else a force which constrains us to stay within certain limits? There is no way of returning to the Ancients on this score and no solution should be sought by so doing. Nevertheless, it is possible to study the positions they adopted, and they left a variety of documents on their religious beliefs.

On 4. The myths have come to win our interest again. Today more than ever we are conscious that mythological thought exists alongside the rational. Just to cite a single example, Roland Barthes had given us the clearest evidence of the "mythological" in the most modern products. And we shall benefit from studying the Romans' double conception of history as (a) the prehistory of the present and (b) a storehouse of exempla requiring the reader to follow them.

On 3. Greek and Roman history offer plenty of material for studying the question of regionalism versus centralism, a fundamental one for the German Federal Republic, which also arouses as great an interest in Great Britain and many other European states, not least in the "Latin" countries, Italy, France, Spain, Belgium.

On 2. The eternal conflict between theory and practice has its specific forms today. A technology which posits that "everything is possible" exposes its own theoretical bankruptcy. Furthermore, political and economic theories are belied so cruelly by actuality that they lose all credibility. As against these contradictions, it seems to us to be a more limited problem which Cicero faced in trying to persuade his fellow-citizens that, for exemple, rhetoric, for all it was a craft in the hands of the lawyers' (the patroni), needed theories and philosophical doctrines, which in his time meant Greek ones.

On 1. I have already spoken of the differences in kind between the two languages and of the consequences that arise from them. These can be thrown into relief by means of a teaching method employing contrast or comparison between the languages. But a third partner immediately appears on the scene: our own native language. Careful reflexion on the properties of the three languages will maximise both linguistic and cultural awareness.

\section{Conclusion}

The form of a brief account only allows me to skim over the points I have made, although there is plenty to be said about each and still more working out to be undertaken in order to put at teachers' disposal the material requisite for bringing to full development the two subjects which have been contrasted. Finally I should like to rise one last point of great importance.

10. It is the fact that the Greek world and the Latin ${ }^{7}$ world present themselves to us each in quite a different way. It is only our own organised teaching which tends to obscure this diversity somewhat, as I have suggested at the beginning of this account.

In fact there is a solid cultural continuity between ourselves and Latin ${ }^{8}$. This is of course only true, as far as Western Europe is concerned. For the heirs of the Eastern half of the Roman Empire the problems must be put in a different way ${ }^{9}$. But we feel ourselves still in manifest contact with the Roman world, firstly linguistically, especially in the lands where a language of Latin origin is spoken, then through institutions, especially ecclesiastical and judicial ones, and through all the other remains found in our history. In particular there is the continuity in the world of learning which until the nineteenth century communicated in Latin 
and which still makes ample use of it for the needs of scientific, psychological, sociological, economic and technological terminology. It has to be admitted of course that Greek is used even more than Latin in this respect.

What, on the other hand, is our contact with the Greek world? First of all, Greek influence made itself felt on the Roman world and this is the modest legacy which was transmitted to us across the middle ages. For a long period of time, the Greek language was as good as forgotten in our part of the world. Our relationship with Greek has been marked rather by repeated but momentaneous meetings, but not by a continuity. Such were the Renaissence, the humanists, the neohumanists (such as Winckelmann, Herder, and Goethe, and also parallel movements in other countries). These meetings were momentaneous, yet had profound effects. They also took place at long distance, deprived of geographical and political contact, without the transmission of any legacy other than a spiritual and artistic one, which makes their repercussions all the more remarkable, yet at the same time all the more fragile!

The list of contrasting points offer material for many discussions and conclusions. I shall confine myself to three simple points which are directly relevant to our teaching.

1. It is clear that there are excellent reasons to go on teaching both ancient languages and to cultivate them side by side.

2. In the deplorable situation where only one language can be taught, there is no sufficient reason automatically to prefer Latin to Greek. The widely found preference for Latin has an historical explanation but has no basis in the content of the two subjects.

3. Whether the two languages are taught under the same roof or whether only one subsists, it is essential to include in the teaching of each the aspects in which it contrasts with the other.

This was precisely the point of this essay: to rekindle awareness of some contrasts inherent in the two ancient civilisations such as are able to emphasise the individuality of each, and thus create a yet richer combination.

\section{Notes}

1-This research was undertaken by my colleague and friend W. Heilmann, in an article in Handbuch fuer den Lateinunterricht - Sekundarstufe II (Latin Coursebook for Upper Secondary Classes), Frankfurton-Main, 1979. Diesterweg, pp. 58 to 69. To this article I owe most of the points I have propounded here. A more direct response to Heilmann's article is forthcoming in Latomos, 1985. See also the bibliographical note.

2 -Translator's note: the word "tribe" is here used loosely for want of a better to refer to the broad divisions of the Greeks into Ionians, Dorians, etc., and not to the tribes in historical Greek cities.

3 - Sallust, in a single sentence in Catiline 9, 4, already noted this attitude.

4 - In the political language of present-day Germany the same thing happens with the word Systemveraenderer (lit. "one who wants to change the system"). In some people's mounths it has become a word heavy with reproach.

5 - This series of contrasts is developed in F. Wieacker, p. 52.

6 -The Roman Church took over from the Empire in founding itself on quite a lot of its structures. Thus it succeeded to a power which has no theological basis.

7 - Latin, not just Roman!

8 -Not with standing that there has been a growing number of interruptions in this continuity during our own century.

9 -This article was first written for a lecturetour to Greece, originally to elicit an exchange of views with Greek collegues. It was published, in Greek, in the Espistemoniki Epetiris of the Philosophy Faculty, Salonika University. No. 21, 1983, pp. 491 to 512. The problem still remains (among others) to discover how far contemporary Greeks can come to see that the Byzantine world contained a strong Roman element and that their line of descent does not go back purely and directly to Pericles, Sophocles, Thucydides, and Plato. The object of this 
note is not to relate a biographical detail, but is meant to revel the importance of comparing, between nation and nation, our understanding of the credentials of the subjects we teach. The case of modern Greece is but the extreme case of the diversities which exist between all our countries.

10 - Professor Alan Wardman supplied the English bibliography.

\section{Bibliographical note}

Besides the article cited in note 1 it must be stated how few sources exist on the subject of contrasting and comparing the Greeks and Romans. I have found scattered information in a number of classic works e.g. Nietzsche, The Birth of Tragedy, subtitled "Greekness and Pessimism", and Jakob Burckhardt, History of Greek Civilisation; then, in more recent works, not widely known even in Germany, such as
Franz Wieacker, Vom roemischen Recht (2nd ed. Stuttgart 1961); Richard Harder, Eigenart der Griechen, Freiburg 1962; and Otto Seel, Roemertum und Latinitaet, Stuttgart, 1964.

The following works in English are also relevant. General: Antony Andrewes, Greek Society, Pelican (1971). Donald Dudley, Roman Society, Pelican (1975). Oral Culture: E. A. Havelock, Preface to Plato, Harvard (1963) and (1982). Myth and Religion: G. S. Kirk, Myth, CUP (1970): Sather Classical Lectures. H. J. Rose, Religion in Greece and Rome, Harper (1959). (A one volume edition of Ancient Greek Religion and Ancient Roman Religion). History: Michael Grant, The Ancient Historians, Weidenfeld (1970). Language: Jorma Kaimio, The Romans and the Greek Language, Societas Scientiarum Fennica, Helsinki (1970). Attitudes of Greeks and Romans: Arnaldo Momigliano, Alien Wisdom, CUP (1975). Alan Wardman, Rome's Debt to Greece, Elek (1976) 